Article

\title{
Steam Oxidation of Aluminide-Coated and Uncoated TP347HFG Stainless Steel under Atmospheric and Ultra-Supercritical Steam Conditions at $700{ }^{\circ} \mathrm{C}$
}

\author{
Alina Agüero ${ }^{1}$ * , Ignacio Baráibar ${ }^{1}$ (D), Marcos Gutiérrez ${ }^{1}$, Satu Tuurna ${ }^{2,3}$, Aki Toivonen ${ }^{2}$, \\ Sami Penttilä ${ }^{2}$ and Pertti Auerkari ${ }^{2}$ \\ 1 Instituto Nacional de Técnica Aeroespacial, Área de Materiales Metálicos, Ctra. Ajalvir Km 4, \\ 28850 Torrejón de Ardoz, Spain; baraibargmi@inta.es (I.B.); gutierrezdom@inta.es (M.G.) \\ 2 VTT Technical Research Centre of Finland Ltd., 02044 Espoo, Finland; Satu.Tuurna@kiwa.com (S.T.); \\ Aki.Toivonen@vtt.fi (A.T.); Sami.Penttila@vtt.fi (S.P.); pertti.auerkari@vtt.fi (P.A.) \\ 3 Kiwa Inspecta, Hautalankatu 31, 33560 Tampere, Finland \\ * Correspondence: agueroba@inta.es
}

Received: 17 July 2020; Accepted: 25 August 2020; Published: 28 August 2020

\begin{abstract}
The efficiency of ultra-supercritical (USC) steam power plants is limited by the materials properties, in particular, the steam oxidation resistance of the currently used steels at temperatures higher than $600^{\circ} \mathrm{C}$. Under these conditions, steam oxidation results in the development of thick oxide scales which spall and can accumulate in tube bends leading to blockage, overheating and premature creep rupture, as well as erosion of downstream components such as steam valves and turbine blades. Most published work related to oxidation testing is carried out at atmospheric pressure, with significantly less testing of austenitic steels in supercritical steam, and rarely including protective coatings. Indeed, the effect of high-pressure steam in the oxidation process is not quite understood at present. This paper covers a comparison of the behaviour of TP347HFG stainless steel at $700{ }^{\circ} \mathrm{C}$ under atmospheric pressure and $25 \mathrm{MPa}$, with and without slurry-applied diffusion aluminide coatings. The results show a very protective behaviour of the aluminide coatings, which develop a very thin Al-rich protective oxide, and no significant difference between the two environments. In contrast, the uncoated steel exhibited a different behaviour. Indeed, under atmospheric pressure after $3000 \mathrm{~h}$, very thin scales, rich in $\mathrm{Cr}$ and not surpassing 5 to $10 \mu \mathrm{m}$ in thickness, covered the samples along with some much thicker Fe-rich oxide nodules (up to $150 \mu \mathrm{m}$ ). However, under $25 \mathrm{MPa}$, a thick multilayer scale with a non-homogeneous thickness oscillating between 10 to $120 \mu \mathrm{m}$ was present. A microstructural investigation was undertaken on the oxidised uncoated and coated substrates. The results suggest that pressure increases the oxidation rate of the chromia former steels but that the oxidation mechanism remains the same. A mechanism is proposed, including early detachment of the outer growing scales under supercritical pressure.
\end{abstract}

Keywords: ultra-supercritical steam; coating; oxidation; aluminide; austenitic steel

\section{Introduction}

The efficiency of ultra-supercritical (USC) steam power plants is currently limited, in part, because of insufficient steam oxidation resistance at temperatures $>600^{\circ} \mathrm{C}$. Indeed, increasing the operating temperature poses a challenge in the selection of materials without significantly increasing costs [1]. In these power plants, the materials are subjected to very severe environments including pressures of $25 \mathrm{MPa}$ and higher. Steam oxidation takes place under these conditions, generating very thick oxide scales, which spall and accumulate in tube bends leading to blockage, overheating and premature creep rupture, as well as erosion of the main steam valves and turbine blades. 
Supercritical water (SCW) is also key for other power generation processes such as SCW-cooled Generation IV nuclear reactors [2]. In this case the conditions are similar but within the $300-650{ }^{\circ} \mathrm{C}$ temperature range. Moreover, $\mathrm{SCW}$ is also being considered for heavy oil (asphaltene and bitumen) refining because of the increasing demand of this resource [3]. In the corresponding plants, temperatures can reach values higher than $600{ }^{\circ} \mathrm{C}$ and the materials are in general austenitic steels or Ni-base alloys, although Ti- and $\mathrm{Zr}$ base materials are also being considered.

In order to validate new alloys or coatings to be used in plants, expensive and uncontrolled conditions testing must be currently carried out in operating plants. More experimental data are needed as a better understanding of supercritical conditions effects as well as the possibility of establishing correlations between laboratory supercritical and atmospheric steam rigs would be very useful, since plant testing is not always available and high-pressure testing facilities are more expensive and challenging to operate.

Few studies have compared the behaviour of materials exposed to real operating conditions in power plants with that observed in the laboratory under atmospheric pressure steam and the results are dissimilar in some cases. For instance, Knödler and Strau $\beta$ compared several ferritic/martensiticand Ni-based alloys tested at: (a) 630 and $725^{\circ} \mathrm{C}$ under high velocity steam at 190 bar in a plant, and (b) at 650 and $750{ }^{\circ} \mathrm{C}$ in the lab under low velocity steam at atmospheric pressure [4]. They found that ferritic/martensitic steels yielded similar results under both conditions, indicating that the steam pressure and velocity did not influence the scale growth. On the other hand, Ni-base alloys showed considerable higher oxidation rates in the plant tests. According to the authors, this may be due to the higher pressure and/or the high frequency of thermal cycling which occurs in the plant. Other factors such as different steam compositions ( $\mathrm{pH}$, oxygen content, etc.) might also play a role. In contrast, Holcomb found different behaviours when he studied several steels and Ni alloys at 267 bar of slowly flowing steam and $670{ }^{\circ} \mathrm{C}$ in a pilot test in the laboratory, and compared them with the observed behaviour under atmospheric pressure [5]. In this case, all studied alloys showed corrosion rates orders of magnitude higher as well as higher thickness scales after $293 \mathrm{~h}$ of exposure to steam under supercritical conditions. In particular, fine-grained austenitic steel TP304H showed a corrosion rate four orders of magnitude higher at 267 bar. Indeed, the oxide scale was significantly thicker with an outer Fe oxide layer and an inner Fe-Cr spinel, whereas at 1 bar very thin pure chromia formed according to the author.

Some other studies related to testing austenitic steels under ultra-supercritical steam can be found in the open literature at temperatures ranging from $600-800{ }^{\circ} \mathrm{C}$, and in general, at higher pressure, higher oxidation rates are observed [6-11]. At lower temperatures $\left(<700^{\circ} \mathrm{C}\right)$, a thin protective $\mathrm{Cr}$-rich oxide accompanied by the presence of deep and large oxide nodules was observed at relative short. At higher temperatures and/or longer exposure times, dual-layer oxides developed, with an outer layer containing $\mathrm{Fe}_{2} \mathrm{O}_{3}$ and $\mathrm{Fe}_{3} \mathrm{O}_{4}$, while the inner layer was composed of $(\mathrm{Fe}, \mathrm{Cr})_{3} \mathrm{O}_{4}$.

Considerable efforts have been dedicated to the development of coatings for super-critical power plants [12-19] but little work has been published regarding the behaviour and coatings under high pressure steam. Coatings such as MCrAlY overlays $(\mathrm{M}=\mathrm{Ni}, \mathrm{Fe})[20,21]$ ceramics such as $\mathrm{Al}_{2} \mathrm{O}_{3}$ [22], and diffusion aluminides deposited by slurry application [23-25] or by pack cementation [26] have been studied over the past few years and in most cases these coatings displayed a substantial improvement in terms of high pressure steam oxidation resistance. For instance, specimens of P92, both uncoated and coated with a slurry aluminide were exposed to real operating conditions in a bypass of a steam power plant and the results were compared to those obtained in the laboratory under atmospheric steam [23]. The authors found that under $180 \mathrm{bar}$ and at $640{ }^{\circ} \mathrm{C}$ uncoated P92 exhibited earlier oxide scale spallation, faster oxide scales growth and a higher degree of porosity than the samples exposed in the laboratory under atmospheric pressure at $650{ }^{\circ} \mathrm{C}$. In contrast, the coatings were very protective after at least $21,700 \mathrm{~h}$ of exposure under both conditions, but evidence of faster coating degradation was found for the field-tested specimen, as a significantly thicker protective scale was present under these conditions. As the plant was subjected to many temperature cycles, it is possible that protective 
oxide spallation was intensified, consuming $\mathrm{Al}$ to reform it and therefore, $\mathrm{Al}$ depletion at the surface may occur faster than under isothermal conditions. Alternatively, high pressure may also have an effect on the protective oxide growth.

When examining these results as a whole, in particular in the few cases on which testing under atmospheric and high pressures is compared, no total agreement is found. Nevertheless, a general tendency can be observed, in particular regarding austenitic steels that develop protective oxides under atmospheric steam with isolated thick un-protective oxide nodules. On the other hand, thick, continuous multi-layered oxides are observed under supercritical conditions even after relatively shorter exposures. Regarding coatings, mostly alumina formers have been examined under supercritical conditions and they remain stable and protective despite the fact that some differences have been detected as for instance by Boulesteix and coworkers [25] who observed different oxide scale morphologies, as whisker- and plate-like features were detected under flowing atmospheric steam and high stagnant steam pressure respectively. In any case, the dissimilar results obtained by the different authors could be probably attributed to different testing conditions such as linear velocities, water quality and compositions, etc.

In the present work, a study has been carried out to compare the behaviour of slurry aluminide coatings deposited on SS TP347HFG under supercritical (25 MPa) as well as atmospheric flowing steam at $700{ }^{\circ} \mathrm{C}$. The uncoated material that is a chromia former, was also tested and the evolution of the corresponding oxides as well as that of the coating microstructure was studied up to $3000 \mathrm{~h}$. The aim was to gain further understanding on the effects of steam pressure on the oxide morphologies and the oxidation rates on both $\mathrm{Cr}$ and $\mathrm{Al}$ protective oxide former materials. As a result of this investigation, a steam oxidation mechanism for austenitic steels is proposed.

\section{Experimental Part}

\subsection{Materials}

Sample coupons $(20 \mathrm{~mm} \times 10 \mathrm{~mm} \times 3 \mathrm{~mm})$ of TP347HFG were machined from the wall thickness of a cold finished seamless tube obtained from Sumitomo Metal Industries LTD (Tokyo, Japan). The actual and nominal compositions are shown in Table 1. The samples were ground with 1200 Emery paper prior to testing. Al powder (particle size 4-6 $\mu \mathrm{m}$ ) was obtained from Bende-Lutz Werker GmbH.

Table 1. Composition of TP347HFG stainless steel from Sumitomo Metal Industries LTD (Tokyo, Japan).

\begin{tabular}{ccccccccccc}
\hline \multicolumn{2}{c}{ Chemical Composition (wt.\%) } & $\mathbf{C}$ & $\mathbf{S i}$ & $\mathbf{M n}$ & $\mathbf{P}$ & $\mathbf{S}$ & $\mathbf{C r}$ & $\mathbf{N i}$ & $\mathbf{N b}+\mathbf{T a}$ & $\mathbf{F e}$ \\
\hline \multicolumn{2}{c}{ Test material } & & 0.09 & 0.36 & 1.4 & 0.02 & 0.01 & 18.3 & 11.4 & 0.9 \\
Nominal & $\min$ & 0.06 & - & - & - & - & 17.0 & 9.0 & $8 \times C$ & balance \\
& $\operatorname{Max}^{(1)}$ & 0.10 & 0.75 & 2.00 & 0.04 & 0.03 & 20.0 & 13.0 & 1.0 & balance \\
\end{tabular}

(1) TP347HFG (VdTÜV WB 547).

\subsection{Coating Deposition}

The Al slurry is a Cr VI free, water-based proprietary composition paint, containing spherical Al particles (nominal average $\emptyset: 5 \mu \mathrm{m}$ ), a binder constituted by a mixture of non-toxic inorganic compounds developed by INTA and water as solvent. The mixture was stirred by means of a magnetic bar prior to coating and the sample's surface was ground and solvent degreased. The slurry was applied at room temperature by spraying with a Sagola spray gun (spray distance: $250 \mathrm{~mm}$; pressure: 2 bar), and the coated samples were left to dry under laboratory air and then subjected to a diffusion heat treatment performed under vacuum at $700{ }^{\circ} \mathrm{C}$ for $1 \mathrm{~h}$ followed by $5 \mathrm{~h}$ at $900{ }^{\circ} \mathrm{C}$. Finally, slight cleaning with a Scotch Brite sponge was undertaken to remove undiffused slurry residues (bisque). More insight into the deposition procedure can be found elsewhere [27]. 


\subsection{Atmospheric Pressure Steam Oxidation Testing}

The schematics of the closed loop laboratory tubular rig employed at INTA are shown elsewhere [28]. Prior to testing, laboratory air is displaced from the chamber by means of $\mathrm{N}_{2}$ which is kept flowing at $150 \mathrm{~L} / \mathrm{min}$ while heating up to the test temperature (approximately at $600^{\circ} \mathrm{C} / \mathrm{h}$ ). Once the test temperature is achieved $\left(700^{\circ} \mathrm{C}\right)$, the $\mathrm{N}_{2}$ flow is closed and pure steam is introduced at a linear velocity of $8 \mathrm{~cm} / \mathrm{s}$. Water used to produce steam is constantly bubbled with $\mathrm{N}_{2}$ and the $\mathrm{pH}$ is maintained at 7. To carry out weight measurements or to remove samples for metallographic analysis, the furnace is cooled to $\sim 300^{\circ} \mathrm{C}$ under $\mathrm{N}_{2}$ and the specimens are subsequently removed. The reheat cycle is also carried out under $\mathrm{N}_{2}$. At least three samples per exposed time where weighted.

\subsection{High Pressure Steam Oxidation Testing}

The high-pressure steam test was carried out at VTT in a custom built recirculating supercritical water autoclave at $700{ }^{\circ} \mathrm{C} / 25 \mathrm{MPa}$ with $150 \mathrm{ppb}$ dissolved oxygen at the inlet flow and a $\mathrm{pH}$ of 7 , measured at room temperature in the low-pressure part of the recirculation loop. The test environment was the same during all heating and cooling cycles, except when the autoclave was opened for sample retrieval at room temperature. At least three samples per exposed time where weighted.

The heating rate at the start of testing sequences was $20^{\circ} \mathrm{C} / \mathrm{min}$ up to $500{ }^{\circ} \mathrm{C}$ and $7{ }^{\circ} \mathrm{C} / \mathrm{min}$ above this level, and the cooling rate at the end of the testing sequence was $20^{\circ} \mathrm{C} / \mathrm{min}$. The schematics as well as further details of the test rig can be found elsewhere [24]. The flow rate during the exposure was around $7 \mathrm{~mL} / \mathrm{min}$ (of water) resulting in a refresh time of the autoclave volume roughly every $1 \mathrm{~h}$. Specimens were hung on the specimen holder rack using electrically insulating $\mathrm{ZrO}_{2}$ rings.

\subsection{Characterisation}

The coatings were characterised by light microscopy (Leica DV 6) and field emission gun scanning electron microscopy (FESEM) employing a ThermoScientific APREO C-LV (ThermoFisher Scientific, Brno, Czech Republic) microscope equipped with an energy-dispersive $X$ ray microanalysis system (EDX) from Aztec Oxford. Cross section observations were obtained by cutting the specimens with a diamond wheel ATM 92002401, mounting them in conductive resin Konductomet (Buehler, Lake Bluff, IL, USA) and polishing with silice coloidal MarterPolish2 (Buehler, Lake Bluff, IL, USA). The samples were not subjected to etching. Thicknesses were determined by a minimum of 20 measurements and their averages are reported in the text. Phase composition was examined by $X$-ray diffraction (XRD) in a Philips X'Pert equipment (Panalytical, Almello, Holland) using the $\mathrm{Cu} K \alpha$ line $0.15418 \mathrm{~nm}$.

\section{Results}

\subsection{Initial Coating Microstructure}

Slurries are suspensions of $\mathrm{Al}$ particles in a binder and are applied as any paint. After drying and curing, a layer of agglomerated Al particles is obtained and when this layer is subjected to appropriate heat treatment, $\mathrm{Al}$ melts and partially dissolves the substrate forming intermetallics, which solidify and later evolve depending on the heat treatment length and temperature. In the present case, a heat treatment consisting of $1 \mathrm{~h}$ at $700{ }^{\circ} \mathrm{C}$ followed by $5 \mathrm{~h}$ at $900{ }^{\circ} \mathrm{C}$ under vacuum was applied and a three-zone coating microstructure measuring $\sim 100 \mu \mathrm{m}$ was obtained as shown in Figure 1. The element matrix shows a decreasing $\mathrm{Al}$ content from the surface towards the substrate and the presence of "islands" of Al richer phases as well as a Cr-rich phase within the most external layer (zone 1). According to the composition measured by EDS as well as the XRD pattern (Figure 2), the matrix in zone 1 (Figure 3) corresponds to $\mathrm{Fe}_{2} \mathrm{Al}_{5}$ (Al: 50.9; Fe: 38.7 in wt.\%) with some $\mathrm{Cr}$ and $\mathrm{Ni}(4.6$ and $3.2 \mathrm{wt} . \%$ ). The Al-poorer zones correspond to FeAl (Al: 33.0; Fe: 49.8 in wt.\%) with Ni (6.2 wt.\%) and $\mathrm{Cr}\left(8.3\right.$ wt.\%), and the Cr-rich phase to $\mathrm{Cr}_{2} \mathrm{Al}_{13}$ (Al: 64.8; Cr: 15.0 in wt.\%). Some peaks matching $\mathrm{NiAl}$ could also be observed in the XRD pattern. In addition, submicron scale precipitates rich in $\mathrm{Nb}(\sim 45 \mathrm{wt} . \%)$ can also be detected throughout the coating and can be attributed to $\mathrm{Nb}$ carbides and 
carbonitrides which are present in alloy TP347HFG [29]. Indeed, low intensity peaks corresponding to $\mathrm{Nb}(\mathrm{C}, \mathrm{N})$ could also be identified in the XRD pattern. The intermediate layer composition (zone 2 in Figure 1) corresponds again to $\mathrm{FeAl}$ (Al: 34.1 ; Fe: 49.8 in wt.\%) with some $\mathrm{Ni}(6.8 \mathrm{wt} . \%)$ as well as dissolved $\mathrm{Cr}(9.4 \mathrm{wt} . \%)$ and at the interface with the third and last zone there is a Ni rich thin layer (Figure 1) with Al: 34.2; Fe: 30.4; Ni: 25.1 in wt.\%. In the interdiffusion layer (zone 3 in Figure 1), the $\mathrm{Al}$ content is reduced to $15 \mathrm{wt} . \%$ near the interface with zone 2 and gradually decreases to $3 \mathrm{wt} . \%$ at the interface with the substrate. Likely, this phase is a solid solution of $\mathrm{Ni}, \mathrm{Cr}$ and $\mathrm{Al}$ on Fe. Within this inner layer, some darker grey features can be found, which are richer in $\mathrm{Al}$ and $\mathrm{Ni}$ than the surrounding areas (Figure 4). The same morphological features were observed by Yang et al. who recently produced an aluminide coating on Super $304 \mathrm{H}$ alloy with a different heat treatment than ours and a different overall morphology [19]. However, within the interdiffusion zone (zone 3 in our case), they were able to identify these features (called "butterflies" in their case) as NiAl, by electron diffraction, in agreement with our results. Dark AlN precipitates are also present in this zone in our case, resulting from $\mathrm{N}$ present in the alloy, as it reacts with incoming Al. This zone is also rich in $\mathrm{NbC}$ precipitates as shown in the corresponding mapping in Figure 4.



Figure 1. FESEM cross section SE image and EDS element map of a slurry aluminide coating deposited on HT347HFG steel after being heat treated for $1 \mathrm{~h}$ at $700{ }^{\circ} \mathrm{C}$ and $2 \mathrm{~h}$ at $900{ }^{\circ} \mathrm{C}$.

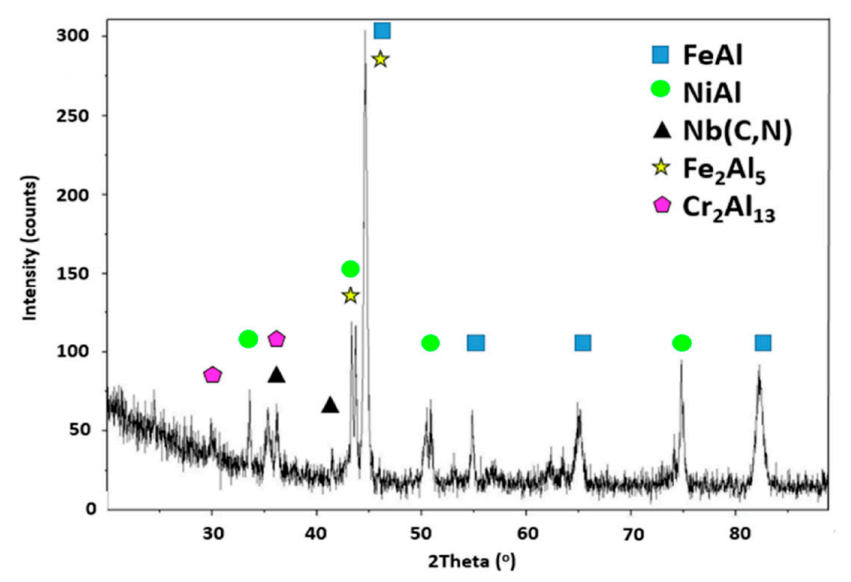

Figure 2. XRD pattern of a slurry aluminide coating deposited on HT347HFG steel after being heat treated for $1 \mathrm{~h}$ at $700{ }^{\circ} \mathrm{C}$ and $2 \mathrm{~h}$ at $900{ }^{\circ} \mathrm{C}$. 




Figure 3. FESEM cross section and element map of the external layer (zone 1 in Figure 1) of the slurry aluminide coating deposited on HT347HFG steel.


Figure 4. FESEM cross section of the most internal layer (zone 3 in Figure 1) of the slurry aluminide coating deposited on HT347HFG steel.

\subsection{Steam Oxidation Test Results}

Figure 5 illustrates the mass variation of all tested samples at $700{ }^{\circ} \mathrm{C}$. Under atmospheric steam pressure, no significant weight differences between the coated and uncoated specimens could be observed, except perhaps between the samples exposed for $3000 \mathrm{~h}$, as the coated specimens exhibited lower weight gain. In contrast, the uncoated substrate experienced considerable weight loss after $300 \mathrm{~h}$ of exposure under supercritical conditions, and then the samples began to gain weight up to more than $1.5 \mathrm{mg} / \mathrm{cm}^{2}$ after $3000 \mathrm{~h}$. This was explained by evidence of substantial spallation of the $300 \mathrm{~h}$ specimens, as shown in Figure 6, where images of the specimens before and after $300 \mathrm{~h}$ of exposure to supercritical steam are presented. After longer exposure, the scale regrew but there is also evidence of a significantly smaller degree of spallation as observed on the sample exposed for $3000 \mathrm{~h}$ in Figure 6. A similar behaviour was observed by Tepylo and coworkers [26] and also by Chen and collaborators [11] who pointed out that this is not often observed by other authors, due to too low testing temperatures or to too short exposure times. Chen observed weight loss for TP347H after $1500 \mathrm{~h}$ at $6500^{\circ} \mathrm{C}$, whereas in the data showed by Tepylo, at $700{ }^{\circ} \mathrm{C}$ significant weight loss was observed for $304 \mathrm{SS}$ after $1000 \mathrm{~h}$. 


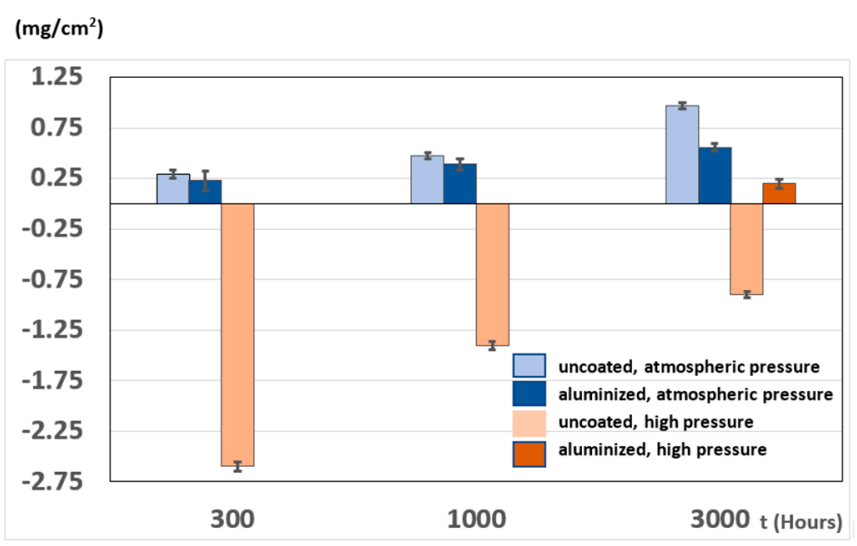

Figure 5. Mass variation of all tested specimens as a function of time exposed to steam at $700{ }^{\circ} \mathrm{C}$.

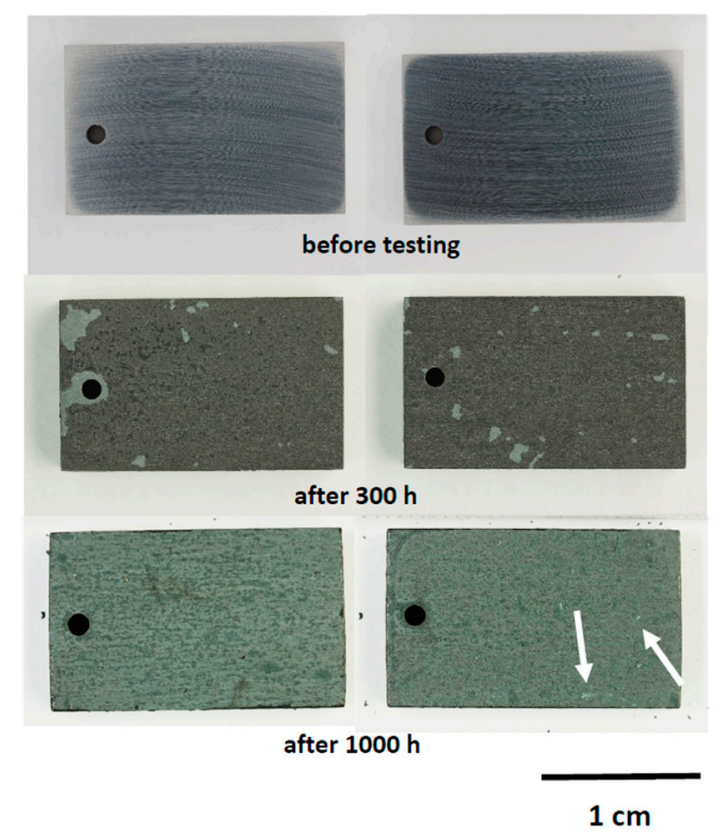

Figure 6. HT347HFG specimens before and after exposure to steam at $25 \mathrm{MPa}$ at $700{ }^{\circ} \mathrm{C}$.

Unfortunately, intermediate weights were not recorded for the coated specimens tested under supercritical conditions but after $3000 \mathrm{~h}$ the corresponding specimens gained less than $0.2 \mathrm{mg} / \mathrm{cm}^{2}$.

\subsubsection{Uncoated TP347HFG}

In Figure 7, the cross sections of the uncoated specimens exposed to steam both at atmospheric and supercritical pressures are shown for all the test intervals. Under atmospheric pressure, TP347HFG is mostly un-attacked by steam oxidation, but exhibits oxide nodules which appear to grow in width and thickness as the exposure time increases, reaching up to $150 \mu \mathrm{m}$ in some nodules after $3000 \mathrm{~h}$. In contrast, under supercritical steam an irregular double layer scale develops and grows up to $120 \mu \mathrm{m}$ after $3000 \mathrm{~h}$. The apparent lower thickness of the oxides developed under supercritical steam compared to that of the oxide nodules formed under atmospheric steam, may be caused by the already mentioned initial oxide spallation experienced under supercritical conditions. In fact, on the sample exposed for $300 \mathrm{~h}$, only some residues of the outermost layer appear on some areas of the shown image. 




Figure 7. Light microscope cross section of HT347HFG specimens exposed to steam at $700{ }^{\circ} \mathrm{C}$ as a function of time and pressure.

The XRD patterns of the samples tested for $3000 \mathrm{~h}$ under atmospheric and supercritical conditions are shown in Figure $8 \mathrm{a}, \mathrm{b}$ respectively. Under atmospheric pressure, the pattern corresponds mostly to the substrate but there are low intensity peaks matching $\mathrm{Fe}_{2} \mathrm{O}_{3}$ and $(\mathrm{Fe}, \mathrm{Cr})_{3} \mathrm{O}_{4}$, whereas under supercritical steam, no substrate peaks could be detected and high intensity peaks corresponding to $\mathrm{Fe}_{2} \mathrm{O}_{3}$ and $(\mathrm{Fe}, \mathrm{Cr})_{3} \mathrm{O}_{4}$ were present. Spinel $\mathrm{Fe}_{3} \mathrm{O}_{4}$ could also be present, as the XRD peaks corresponding to this phase overlap with those of $(\mathrm{Fe}, \mathrm{Cr})_{3} \mathrm{O}_{4}$. This is coherent with the findings of several authors $[10,11]$ and is also supported by the microscopy investigation carried out by light and FESEM microscopy in this work as shown below.

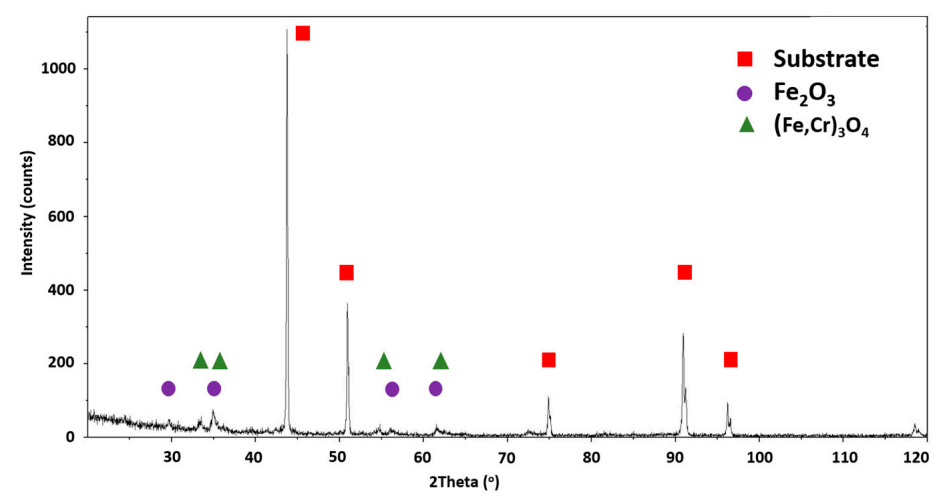

(a)



(b)

Figure 8. XRD patterns of HT347HFG steel exposed to steam at $700{ }^{\circ} \mathrm{C}$ under: (a) atmospheric pressure and (b) $25 \mathrm{MPa}$. 


\subsubsection{Microstructure of the Oxide Scales Developed under Atmospheric Steam}

A $\sim 5 \mu \mathrm{m}$ oxide covers most of the surface of the samples exposed to atmospheric pressure, allowing the peaks of the substrate to be picked up by XRD. In Figure 9, a FESEM cross section of this sample is shown, exhibiting one of the nodules as well as the protective oxide which covers most of the sample surface. The thin protective oxide is rich in $\mathrm{Cr}$, Fe and $\mathrm{Mn}$ and is fractured on most of the examined surface, likely because of the metallographic preparation, and therefore appears to be brittle. A higher magnification image of this $4-5 \mu \mathrm{m}$ oxide is shown in Figure 10 at a section on which it had not fractured. It appears to be a single layer, but when examining the EDS element map, different compositions are detected as a function of the layer depth, and a very thin Si-rich oxide is also present at the scale-substrate interface. It has been found that in the presence of enough $\mathrm{Si}$, this very thin oxide forms and behaves as a diffusion barrier improving the oxidation resistance [30]. Indeed, $\mathrm{Li}$ and coworkers also observed this layer by TEM microscopy on SS310 exposed to atmospheric steam pressure at $625^{\circ} \mathrm{C}$ [6]. Right on top of this layer, a thin $\mathrm{Cr}(23.7 \mathrm{in} \mathrm{wt. \% )}$ and $\mathrm{Mn}$ (4.5 in wt.\%) containing oxide measuring less than $1 \mu \mathrm{m}$ is observed, and is in turn covered by an Fe-rich thicker oxide containing Mn (4.1 in wt.\%) and very little Cr (3.5 in wt.\%). Behnamian et al. [10] found a similar oxide microstructure when exposing $316 \mathrm{SS}$ to supercritical steam at $25 \mathrm{MPa}$ and $800{ }^{\circ} \mathrm{C}$ for only $12 \mathrm{~h}$, but for TP347HFG only a single composition layer was found which they attributed to $(\mathrm{Fe}, \mathrm{Mn}) \mathrm{Cr}_{2} \mathrm{O}_{4}$. The elemental analysis of the external layer in our case is compatible with $(\mathrm{Fe}, \mathrm{Mn})_{3} \mathrm{O}_{4}$, whereas the inner layer is likely $(\mathrm{Cr}, \mathrm{Mn})_{2} \mathrm{O}_{3}$. This was also proposed by Yang and coworkers to form on $304 \mathrm{H}$ after $1000 \mathrm{~h}$ under flowing steam at $650^{\circ} \mathrm{C}$ [19], and by Li et al. when exposing SS310 to supercritical $(29 \mathrm{MPa})$ steam at $625^{\circ} \mathrm{C}$ [6]. The lower $\mathrm{Cr}$ content of the outer zone of the scale may be caused by $\mathrm{Cr}$ evaporation as proposed by other authors [8]. Under this scale a $\mathrm{Cr}$ depletion substrate zone was observed, with only $10.5 \mathrm{wt} . \% \mathrm{Cr}$ as opposed to $18 \mathrm{wt} . \%$ in the bulk alloy.
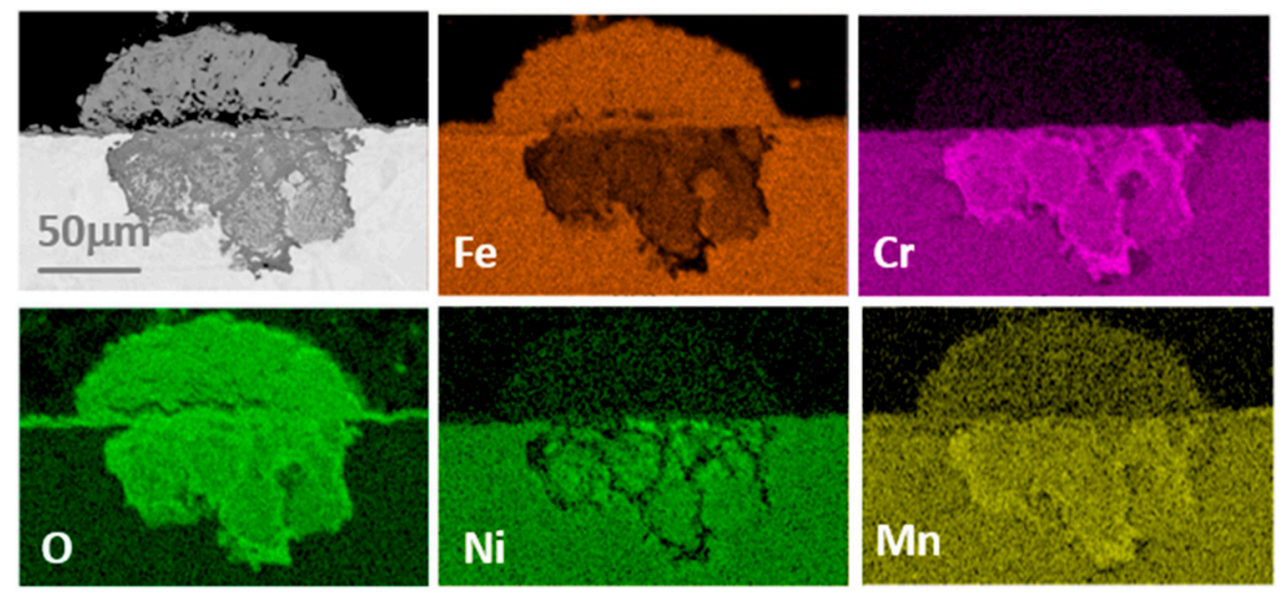

Figure 9. FESEM cross section and EDS element maps of HT347HFG exposed to steam at $700{ }^{\circ} \mathrm{C}$ under atmospheric pressure after $3000 \mathrm{~h}$. 



Figure 10. FESEM cross section of the thin oxide formed on HT347HFG exposed to steam at $700{ }^{\circ} \mathrm{C}$ under atmospheric pressure after $3000 \mathrm{~h}$.

The oxidation nodule shown in Figure 9 presents a complex oxide morphology with an external Fe-rich layer corresponding to $\mathrm{Fe}_{2} \mathrm{O}_{3}$ according to EDS and XRD and an internal complex Cr-rich zone. It has already been accepted by many authors that this two-layered oxide results from Fe outwards diffusion forming the outer layer, and oxidising species inwards diffusion resulting in Cr-rich spinel formation. The external oxide exhibits a high degree of porosity near the interface with the internal oxide (see also Figure 7). In addition, this outer portion of the nodule appears to grow on top of a thin $\mathrm{Cr}-, \mathrm{Fe}-$ and Ni-rich oxide which corresponds to the protective oxide which covers most of the sample surface. Underneath, an internal oxidation zone, characterised by intergranular and lath oxidation patterns is observed. In fact, the original substrate grains appear to be surrounded by a Cr- and Mn-rich oxide, and inside the grains, preferential lath boundary oxidation takes place, as exhibited in the EDS element map shown in Figure 11. This confirms that oxygen inwards diffusion is faster along the grain and lath boundaries. Indeed, within the shown grain (Figure 11), metallic un-oxidised zones can still be observed inside the grain. Lath preferential oxidation was also observed by Bischoff and coworkers on ferritic steels [31] and similar microstructures were observed by Li [8] Yang [19] and Tepylo [26] and coworkers on $304 \mathrm{H}$ stainless steel and by Zhu et al. on TP347HFG stainless steel [32] after steam oxidation. In agreement with Chen and coworkers' findings [11], the formation of Cr-rich layers in this inner oxide leads to $\mathrm{Cr}$ depletion and indeed, on the areas surrounding the nodules, $\mathrm{Cr}$ depletion can be observed on the element map showed in Figure 9. According to EDS analysis, Cr content of $14.1 \mathrm{wt} . \%$ was measured, which is lower than that found in the bulk material (18 wt.\%). 



Figure 11. FESEM cross section of internal oxidation zoned formed on HT347HFG exposed to steam at $700{ }^{\circ} \mathrm{C}$ under atmospheric pressure after $3000 \mathrm{~h}$.

The observed porosity between the inner and outer scales, may lead to oxide detachment as for instance in one of the nodules shown in Figure 7 on the specimen exposed to atmospheric steam for $300 \mathrm{~h}$. The outer layer is formed by Fe outwards diffusion and the thin protective layer located at the interface between the outer and inner oxide may hinder Fe outwards diffusion and moreover, the inner spinel oxide appears to be depleted in Fe. For the generation of two layered oxides, Rouillard and coworkers proposed that Fe atoms' outward diffusion caused vacancies that coalesce forming pores at the interface with the inner growing oxide $[33,34]$. The stable $\mathrm{Cr}$-rich oxides present on the inner scale may also slow further Fe diffusion from the substrate.

Regarding the causes of oxide nodule growth on this $\mathrm{Nb}$ containing steel, recent studies verified that the oxidation of $\mathrm{Nb}$-rich phases, or dissolved $\mathrm{Nb}$ in the matrix could promote the failure of protective $\mathrm{Cr}$-rich scales when the austenitic stainless steels are exposed to high temperatures. $\mathrm{Nb}$ oxidation and the generation of stresses leading to cracking and pitting corrosion [35] could cause oxidation through cracks formed in the protective oxide, resulting in the development of oxide nodules such as the one exhibited in Figure 9. For instance, Behnamian found pits related to $\mathrm{Nb}$ when exposing SS $347 \mathrm{H}$ to supercritical steam at $25 \mathrm{MPa}$ at $800{ }^{\circ} \mathrm{C}$ for only $12 \mathrm{~h}$ [10]. In addition, as mentioned earlier, in the present study the protective scale appears to be brittle and prone to cracking so temperature cycles could also result in provoking crack development due to mismatch between the coefficient of thermal expansion of the oxide and the substrate. An alternative explanation to the origin of oxide nodules can be found in the investigations carried out by Halvarsson and coworkers based on Cr evaporation on stainless steel 304 [36]. They suggested that the oxide formed on top of grain boundaries is protective because it is rich in $\mathrm{Cr}$ because of the faster diffusion of $\mathrm{Cr}$ though grain boundaries, but due to $\mathrm{Cr}$ species evaporation, surface areas away from the grain boundaries cannot maintain a $\mathrm{Cr}$-rich protective scale for long exposures.

\subsubsection{Oxide Scales Developed under Supercritical Steam}

The cross section of the sample exposed for $3000 \mathrm{~h}$ to supercritical steam is shown in Figure 12. As mentioned, the thickness of this rather wavy layer is not uniform, suggesting that it develops as a result of the coalescence of nodules as observed in the samples exposed to atmospheric steam (see Figure 7). The top oxide contains mostly Fe with very low amounts of $\mathrm{Mn}$ and $\mathrm{Ni}$ as well, but no $\mathrm{Cr}$. The average Fe content in the oxide is of $64.5 \mathrm{wt} . \%$. The XRD pattern shown in Figure $8 \mathrm{~b}$ is indicative of $\mathrm{Fe}_{2} \mathrm{O}_{3}$, although $\mathrm{Fe}_{3} \mathrm{O}_{4}$ could likewise be present as the corresponding peaks overlap with $(\mathrm{Fe}, \mathrm{Cr})_{2} \mathrm{O}_{3}$ also present in the XRD pattern. In addition, different colorations can be observed within this top oxide in Figures 7 and 12. The inner layer is rather complex as in the case of the nodules formed under atmospheric pressure, and exhibits a lower Fe content which varies from 12 to $34 \mathrm{wt}$.\%. It also contains 
very rich $\mathrm{Cr}$ zones as for instance at the interface with the substrate, as shown in the corresponding element map in Figure 12. At the bottom of the oxide, a grain surrounded by a $\mathrm{Cr}$-rich layer can be observed in analogy with the microstructure seen in the nodule formed under atmospheric steam (Figure 9), which confirms that the oxidation process initiates at the grain boundaries. Surrounding the nodule and the grains, $\mathrm{Cr}$ depletion zones can also be observed with for instance a $\mathrm{Cr}$ content of $11.1 \mathrm{wt} . \%$ at the bottom of the nodule in the substrate zone immediately adjacent. The Cr-rich thin layer found at the interface between the outer and inner scales in the sample exposed to atmospheric pressure after $3000 \mathrm{~h}$, was not found in the case of the specimen exposed to supercritical steam as it probably delaminates along with the outer growing $\mathrm{Fe}_{2} \mathrm{O}_{3}$ scale.
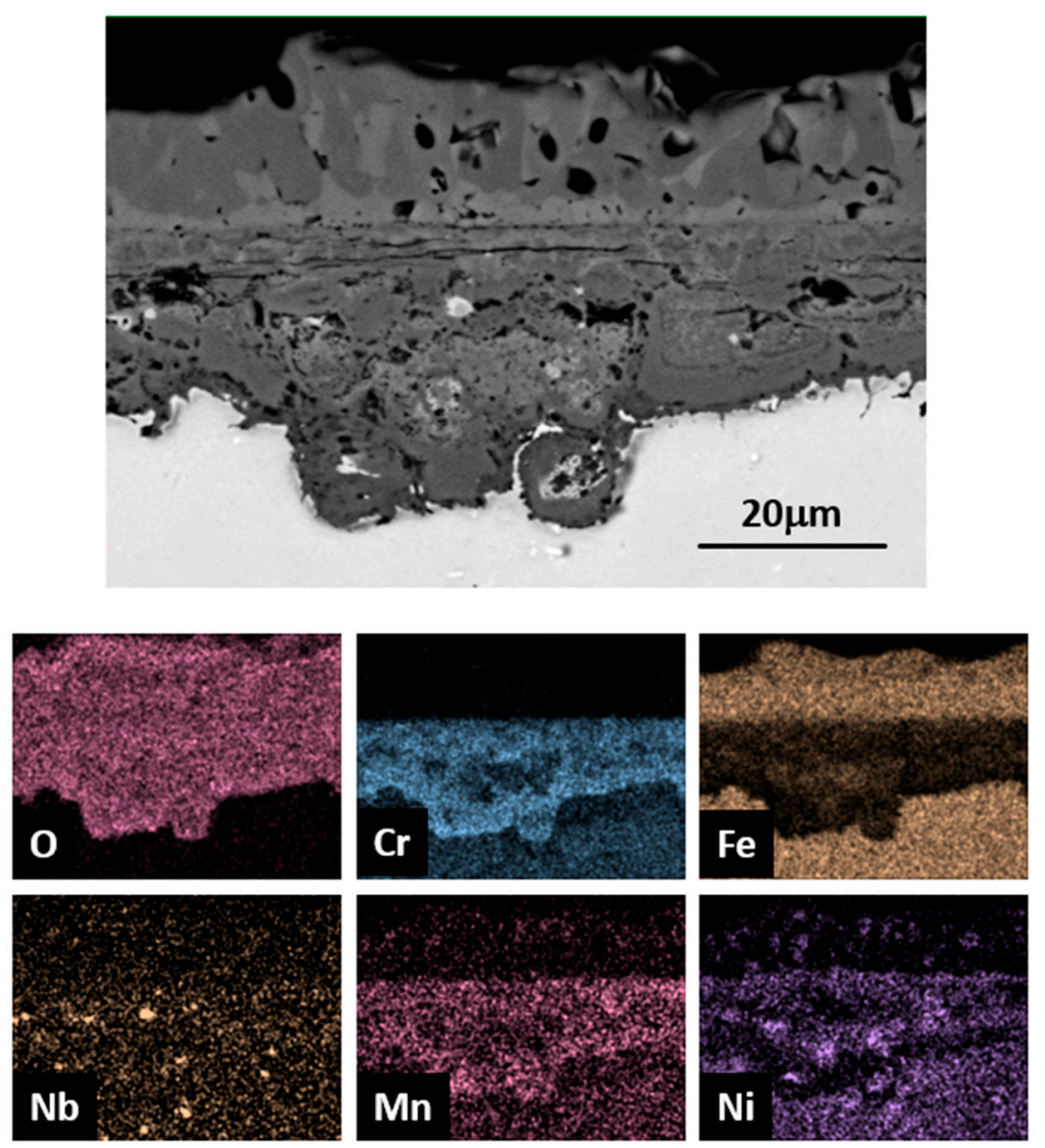

Figure 12. FESEM cross section and EDS element maps of HT347HFG exposed to steam at $700{ }^{\circ} \mathrm{C} 25$ MPa after $3000 \mathrm{~h}$.

As mentioned earlier, delamination of the oxide formed under supercritical conditions takes place mostly at the initial stages of the process and later, regrowth of the scale supersedes the weight loss due to spallation. Tepylo and collaborators also observed oxide spallation on 304 stainless steel at but they only reported the weight loss after $1000 \mathrm{~h}$ so there is no indication on when the spallation took place [26]. On the other hand, Chen reported weight loss only at $650{ }^{\circ} \mathrm{C}$ (not at lower temperatures) and beginning after $1500 \mathrm{~h} \mathrm{[11].} \mathrm{The} \mathrm{optical} \mathrm{micrographs} \mathrm{shown} \mathrm{in} \mathrm{Figure} 7$ indicate that it is the outer layer $\left(\mathrm{Fe}_{2} \mathrm{O}_{3}\right)$ that mostly spalls at the beginning, and then it reforms and spallation continues with exposure time but very likely at a lesser rate.

\subsubsection{Slurry-Aluminised TP347HFG}

As shown in Figure 5, the aluminised specimens gained very little weight after $3000 \mathrm{~h}$ at $700{ }^{\circ} \mathrm{C}$ under both atmospheric and supercritical steam. These results contrast with those obtained by Tepylo 
and coworkers [26] who observed slight weight loss when exposing pack cementation-deposited aluminide coatings on SS 304 to supercritical steam at $700{ }^{\circ} \mathrm{C}$. The authors however, indicated that the coatings exhibited defects that led to substrate oxidation.

Figure 13 shows the coating microstructure evolution as a function of time for the specimens exposed to atmospheric steam. No degradation by oxidation is apparent and the main significant changes are the transformation of the outer layer (zone 1) and the increase in thickness of the interdiffusion zone (zone 3), no doubt caused by coating-substrate interdiffusion. The $\mathrm{Al}$ content at the surface diminished from an initial $50.9 \mathrm{wt}$.\% corresponding to the $\mathrm{Fe}_{2} \mathrm{Al}_{5}$ intermetallic phase to $25 \mathrm{wt} . \%$ in the sample exposed for $3000 \mathrm{~h}$ indicating that the $\mathrm{Fe}_{2} \mathrm{Al}_{5}$ has transformed into $\mathrm{FeAl}$. Since there is no weight loss nor evidences of protective scale spallation, it can be concluded that the transformation into to a lower $\mathrm{Al}$ containing intermetallic phase is caused by $\mathrm{Al}$ inwards diffusion, as further supported by the increase in thickness of zone 3 (interdiffusion zone). The presence of Kirkendall porosity between zones 2 and 3 was also observed, as a result of relatively faster outwards diffusion of the elements of the substrate than $\mathrm{Al}$ inwards diffusion.



Figure 13. FESEM cross sections of aluminide coated HT347HFG exposed to atmospheric pressure steam at $700{ }^{\circ} \mathrm{C}$ as a function of time (hours).

Some cracks perpendicular to the samples' surface that are typical of Fe aluminide coatings also appeared. Fe-Al intermetallics tend to be brittle and the thermal cycles associated with the test interruptions to extract samples are likely behind this. Slurry aluminide coatings deposited on ferritic steels develop cracks after the initial diffusion heat treatment. It has been shown that these cracks do not propagate into the substrate, nor allow steam to reach the substrate even after more than $70,000 \mathrm{~h}$ of exposure to steam under cyclic conditions at $650{ }^{\circ} \mathrm{C}$ as they self-heal by developing protective $\mathrm{Al}_{2} \mathrm{O}_{3}$ on their surfaces [17].

Figure 14 shows the cross sections of the samples exposed to both atmospheric and supercritical conditions for $3000 \mathrm{~h}$ at $700^{\circ} \mathrm{C}$. No substantial difference between the two can be appreciated regarding both microstructure and composition. Both samples exhibit a two-zone coating with similar thickness and the surface $\mathrm{Al}$ content of both samples is $~ 25-28 \mathrm{wt} . \%$ and it is kept constant as a function of depth, up to the interface with the interdiffusion layer (zone 3 ).



(a)

(b)

Figure 14. XRD pattern of slurry-aluminised HT347HFG steel exposed to steam at $700{ }^{\circ} \mathrm{C}$ for $3000 \mathrm{~h}$ under: (a) atmospheric pressure and (b) $25 \mathrm{MPa}$ including a higher magnification of the low intensity peaks. 
The XRD patterns of these two samples (Figure 15) display the FeAl phase, confirming the full transformation of the initial $\mathrm{Fe}_{2} \mathrm{Al}_{5}$ phase present in zone 1 (see Figure 1) to FeAl. Again, although some $\mathrm{Al}$ could have been "spent" in building a protective $\mathrm{Al}_{2} \mathrm{O}_{3}$ scale, most is probably lost from the surface due to interdiffusion between $\mathrm{Al}$ from the coating moving inwards and Fe from the substrate moving outwards. This explains the growth in thickness of the interdiffusion zone that has gone from an initial $\sim 33 \mu \mathrm{m}$ to $\sim 70 \mu \mathrm{m}$ after $3000 \mathrm{~h}$. The XRD pattern of the sample exposed to supercritical pressure exhibits very low intensity peaks corresponding to $\alpha-\mathrm{Al}_{2} \mathrm{O}_{3}$. An Al-rich oxide scale with approximately the same thickness $(\sim 2-5 \mu \mathrm{m})$ is present on the samples exposed to both conditions (Figure 15a,b), although XRD peaks corresponding to $\alpha-\mathrm{Al}_{2} \mathrm{O}_{3}$ could not be detected on the sample exposed to atmospheric steam. The element mapping of the oxide formed on the samples exposed to atmospheric steam is shown in Figure 16 confirming that the oxide is $\mathrm{Al}_{2} \mathrm{O}_{3}$. The same element distribution is observed on the mapping of the corresponding supercritical steam sample (not shown). In earlier work carried out in our laboratory [37], we found that under atmospheric steam at $650{ }^{\circ} \mathrm{C}, \chi-\mathrm{Al}_{2} \mathrm{O}_{3}$ forms on slurry aluminide coatings at the initial stages but that it slowly transforms into $\alpha-\mathrm{Al}_{2} \mathrm{O}_{3}$.

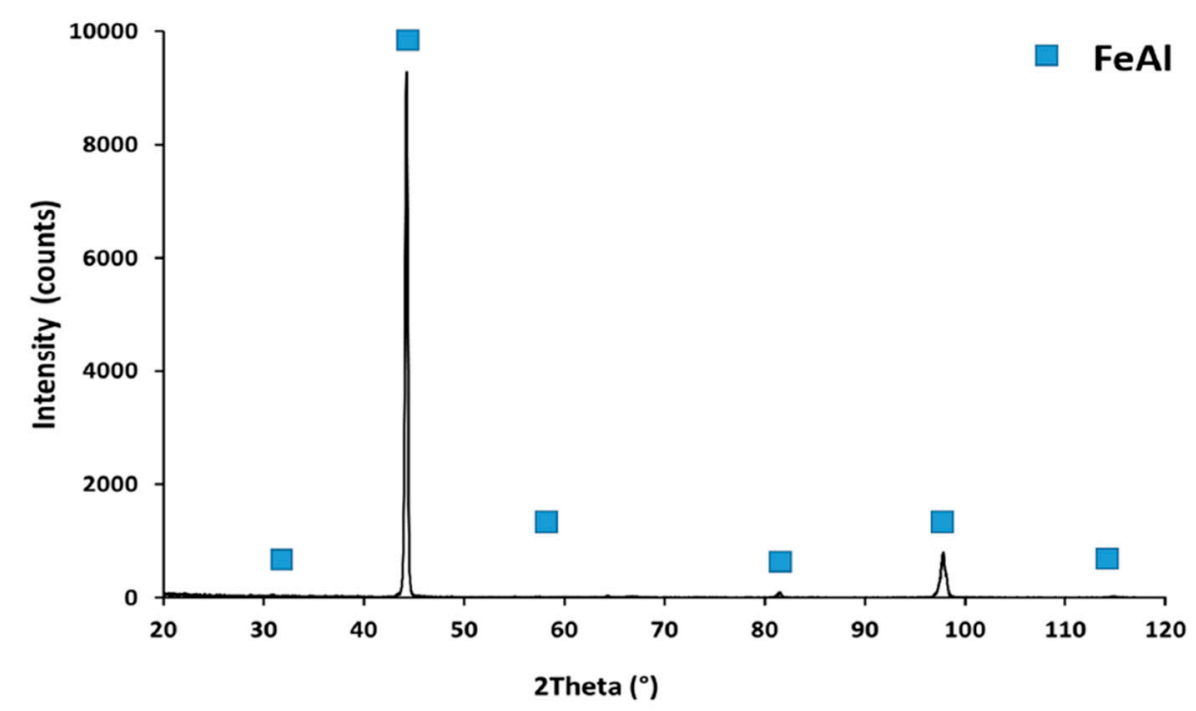

(a)

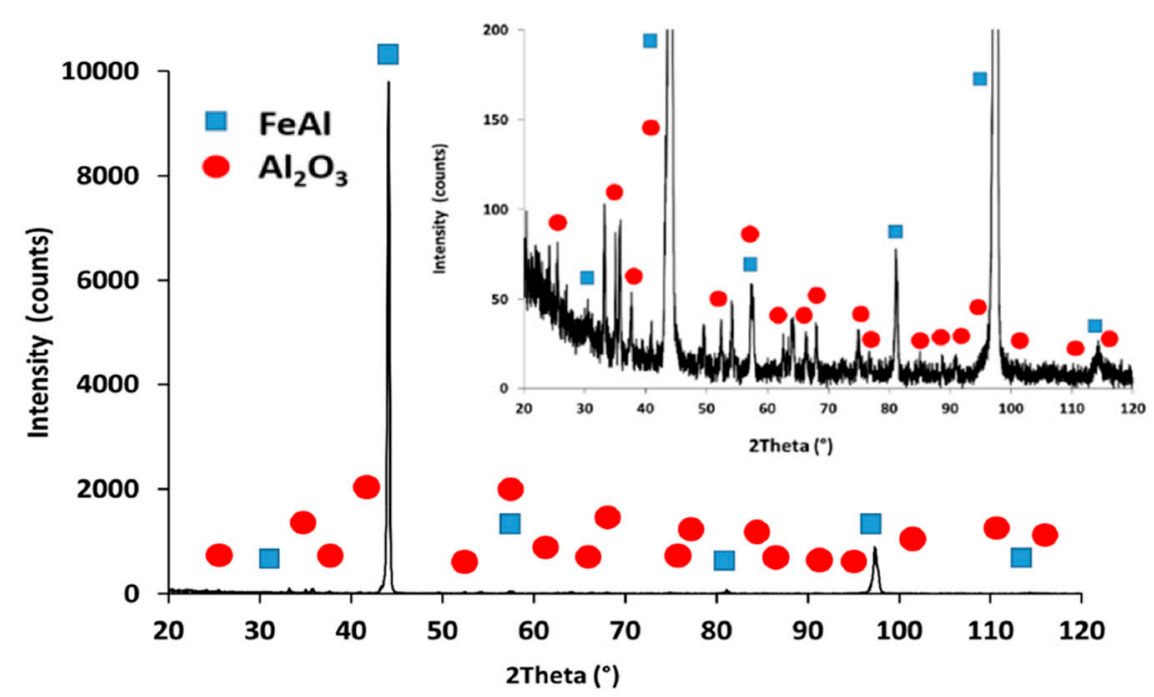

(b)

Figure 15. XRD pattern of slurry-aluminised HT347HFG steel exposed to steam at $700{ }^{\circ} \mathrm{C}$ for $3000 \mathrm{~h}$ under: (a) atmospheric pressure and (b) $25 \mathrm{MPa}$. 


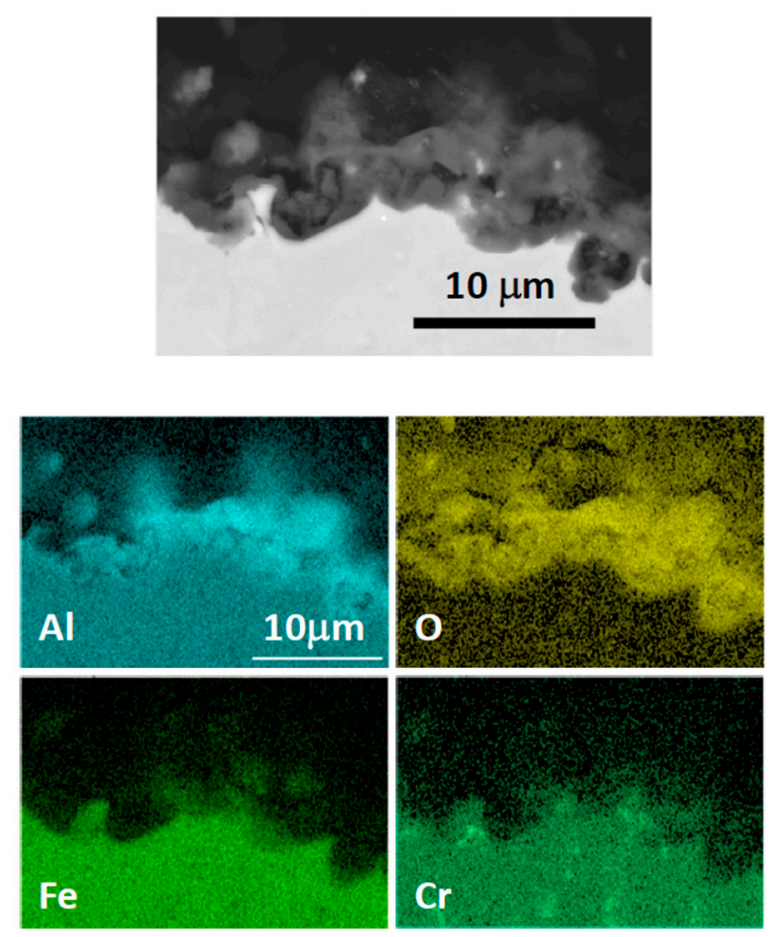

Figure 16. FESEM cross sections of the scale found at the surface of aluminide-coated HT347HFG exposed to steam at $700{ }^{\circ} \mathrm{C}$, at atmospheric pressure and at $25 \mathrm{MPa}$.

Figure 17 shows a high magnification FESEM image of the interdiffusion zone in the sample exposed to atmospheric steam for $3000 \mathrm{~h}$. The same features than those observed in the coating prior to exposure are observed, but after $3000 \mathrm{~h}$ the NiAl precipitates appear more elongated, and aligned perpendicularly to the substrate which may be explained for a preferential growth as the Al diffuses inwards.



Figure 17. FESEM cross section of the interdiffusion layer (zone 3) of the slurry aluminide coating deposited on HT347HFG steel after $3000 \mathrm{~h}$ of exposure to atmospheric steam at $700{ }^{\circ} \mathrm{C}$.

\section{Discussion}

The results of the present work confirm those obtained by most other authors, in that the steam oxidation rate exhibited by austenitic steels is higher under supercritical conditions than under atmospheric pressure steam. Some different causes of this steam pressure-related increase in the oxidation rate have been proposed. These include: (a) increased solid state diffusion within the scales, 
(b) increased hydrogen content in the alloy, (c) a higher content of oxidising species that can absorb on the materials surface increasing the partial oxygen pressure at the interface of the oxide scale and steam and (d) higher rate of Cr evaporation [5,38-40].

Observation of the different type of scales and also their evolution with exposure time leads to propose the following oxidation mechanism (Figure 18):

(1) Initially, under both atmospheric and supercritical conditions, a thin Cr-rich oxide develops the surface of TP347HFG. Such an oxide was the only one observed by Behnamian and workers when exposing several austenitic steels to supercritical steam at $25 \mathrm{MPa}$ and $800{ }^{\circ} \mathrm{C}$ [10] after only $12 \mathrm{~h}$ of exposure. $\mathrm{Cr}, \mathrm{Mn}$ and Fe containing oxides with a thickness of $1 \mu \mathrm{m}$ were observed along with some nodules as in the samples exposed to low atmospheric pressure in our case. Li and collaborators also found a similar Cr-, Mn- and Fe-rich oxide when exposing SS 310 to $29 \mathrm{MPa}$ at $625^{\circ} \mathrm{C}$ for $1000 \mathrm{~h} \mathrm{[6].}$

(2) Thick unprotective nodules develop because of either the presence of $\mathrm{Nb}$-rich carbides in the surface and/or to localised $\mathrm{Cr}$ evaporation, and grow both in thickness and sideways at faster oxidation rate under high pressure, as observed by many other authors. Cracks developed within the protective layer could also lead to nodule formation as the $\mathrm{Cr}$-depleted area under scale may not provide sufficient $\mathrm{Cr}$ to reform the protective scales. Once the nodules begin to form, the outer oxide $\left(\mathrm{Fe}_{2} \mathrm{O}_{3}\right)$ grows in a radial direction form the defect originating the nodule, on top of the thin protective scale.

(3) At high pressure, the oxide grows at faster rates as mentioned, and massive spallation occurs at earlier stages than under atmospheric pressure. Spallation is possibly caused by pore coalescence at the interface between the outer growing hematite layer and the inner growing $\mathrm{Fe}, \mathrm{Cr}$ spinel. Pore development could be caused by the presence of the thin protective oxide which may act as a barrier to Fe outwards diffusion. Stresses generated by radial growth of hematite on top of the original Cr-rich protective thin oxide could also result in the outer oxide detachment. When the top oxide spalls it may carry the Cr-rich layer placed directly underneath.

(4) After spallation, new oxide will grow on top of the inner spinel scale by Fe outward diffusion but at slower rates because of the somewhat protective role of the inner $\mathrm{Cr}$-rich spinel and therefore, overall scale growth will not be as fast as during the initial oxidation stages.

(5) Under higher steam pressure, the growth of these nodules appears to be significantly faster so they end up coalescing after only $300 \mathrm{~h}$.

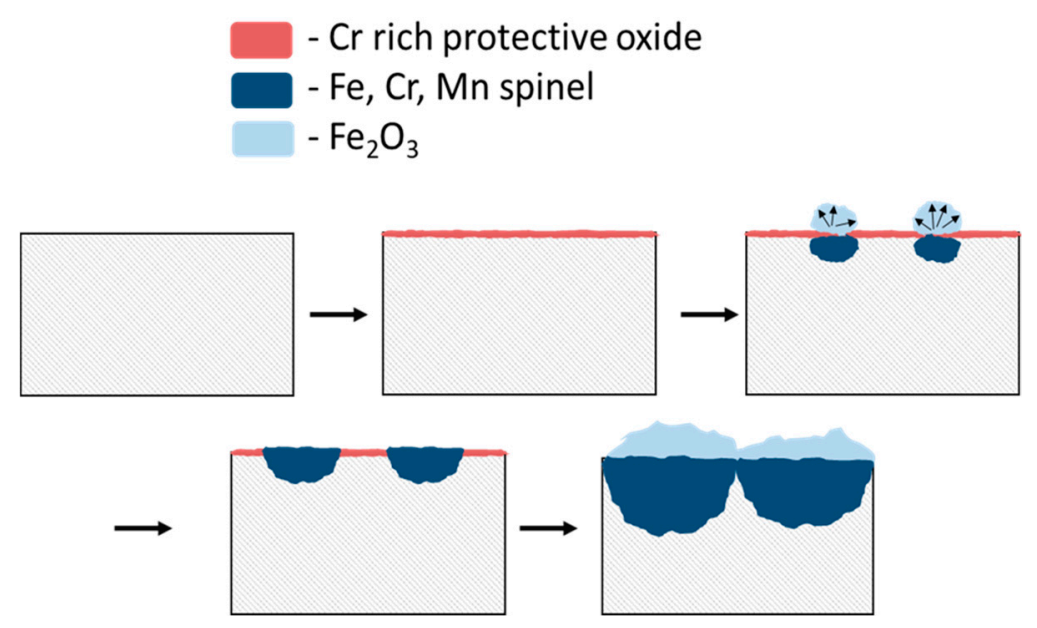

Figure 18. Proposed mechanism for steam for steam oxidation of $\mathrm{HT} 347 \mathrm{HFG}$ at $700{ }^{\circ} \mathrm{C}$. 
In contrast, the slurry aluminide coating appears to behave in the same manner under both atmospheric and supercritical steam, as it develops a protective $\alpha-\mathrm{Al}_{2} \mathrm{O}_{3}$ scale which does not seem to be influenced by pressure up to at least $3000 \mathrm{~h}$. The principal degradation mechanism in this case could be coating-substrate interdiffusion as the concentration of $\mathrm{Al}$ at the surface diminishes as function of exposure time at $700{ }^{\circ} \mathrm{C}$. However, up to $3000 \mathrm{~h}$ the content of $\mathrm{Al}$ is high enough to sustain and maintain the scale, and since diffusion follows a parabolic law, the time required to reach a content of Al lower than the critical amount needed to sustain and reform the scale is expected to be high. Moreover, the relatively high content of $\mathrm{Cr}$ exhibited by these coatings may contribute to reduce the $\mathrm{Al}$ critical content. The appearance of cracks in the coatings both exposed to atmospheric and supercritical conditions, was not surprising given the brittleness of the Fe aluminide intermetallics. However, these cracks do not propagate into the substrate, at least within the tested timeframe.

In an early study, aluminide coatings deposited on ferritic steel P92 [23], a thicker protective oxide was developed on exposure to 180 bar in the bypass of an operating turbine for $21,700 \mathrm{~h}$ at $640{ }^{\circ} \mathrm{C}$, when compared to a similar exposure in the laboratory. Two possible reasons were suggested to explain this behaviour: (1) a higher degree of spallation related to relatively more frequent thermal cycles in the plant and (2) a faster growth and/or spallation/reforming cycles of the protective Al oxide scale caused by higher steam pressures. The as deposited coating had cracks perpendicular to the surface, and in the sample exposed to high pressure steam, the cracks widened to a larger extent but again did not cause substrate oxidation. In contrast, Boulesteix and collaborators found different scale morphologies when exposing aluminide coatings to steam, as under atmospheric pressure, whiskers where observed on the surface of an aluminide coating whereas at 300 bar of stagnant steam there were platelets and clusters after $5000 \mathrm{~h}$ [25]. Although not shown, in the present work we did not observe differences on the cluster-like surface morphology of the coating exposed to both conditions. When comparing these results with those obtained in the present work, we found no evident differences in the behaviour of the coating as a function of pressure. This could be due to a shorter exposure in our case, but also to the fact that our experiment was carried out under flowing steam (Boulesteix high pressure experiment was carried out under stagnant steam [25]) and with significantly less cycles as those experienced in the plant bypass experiment.

\section{Conclusions}

Uncoated and aluminide-coated TP347HFG were exposed to steam at $700{ }^{\circ} \mathrm{C}$ under atmospheric and supercritical conditions up $3000 \mathrm{~h}$. Under supercritical conditions the oxidation rate was higher for the uncoated steel and early massive oxide spallation took place. The results indicate that both under atmospheric and high-pressure steam, a thin protective Cr-rich oxide develops initially on the surface of the steel but oxidation nodules begin to form and grow both in depth and sideways until nodule coalescence takes place. The nodules may form due to: (a) Protective oxide cracking due to thermal cycles; (b) the presence of $\mathrm{Nb}$-rich precipitates at the surface as they oxidise generating stresses and causing pit formation; and (c) localised $\mathrm{Cr}$ depletion away from grain boundaries. After $3000 \mathrm{~h}$ under atmospheric pressure, the protective oxide is still partially present but under supercritical conditions, at exposure times lower than $300 \mathrm{~h}$ the nodules have fully coalesced. The nodules exhibit an outer growing $\mathrm{Fe}_{2} \mathrm{O}_{3}$ scale on top of the thin $\mathrm{Cr}$-rich oxide which in turn covers an inner growing $\mathrm{Fe}, \mathrm{Cr}$, Mn spinel. This inner oxidation process begins at the grain boundaries where Cr-rich oxide is formed. We propose that early massive spallation occurs under supercritical steam due to the higher oxidation rate and the presence of the thin protective scale under the outer growing $\mathrm{Fe}_{2} \mathrm{O}_{3}$ scale which contributes to generate porosity and/or stresses. Under atmospheric steam the same process occurs but at a much lower rate as after $3000 \mathrm{~h}$, extensive areas of the steel surface were still covered by the protective scale as already mentioned.

In contrast, slurry-deposited aluminide coatings protect TP347HFG from oxidation under both conditions by developing a thin protective $\alpha-\mathrm{Al}_{2} \mathrm{O}_{3}$ scale. In this case, no differences in behaviour were perceived under the two examined conditions, indicating that up to $3000 \mathrm{~h}, \alpha-\mathrm{Al}_{2} \mathrm{O}_{3}$ is very stable and 
grows slowly, independently of the steam pressure. The main coating degradation mechanisms are temperature-driven interdiffusion with the substrate, the development of Kirkendall porosity at the interface with the interdiffusion zone and the development of thickness through cracks that stop at the interface with the interdiffusion zone. None of these three degradation modes led to substrate attack up to the experiment exposure timeframe $(3000 \mathrm{~h})$ at $700{ }^{\circ} \mathrm{C}$.

Author Contributions: Conceptualization, A.A., S.T., and P.A.; Investigation, A.A., I.B., M.G., A.T., and S.P.; Methodology, A.A., I.B., M.G., S.T., A.T., S.P., and P.A.; Resources, A.A., I.B., M.G., S.T., A.T., S.P., and P.A.; Writing—original draft, A.A.; Writing — review \& editing, I.B., M.G., S.T., and P.A. All authors have read and agreed to the published version of the manuscript.

Funding: This research was funded by EC for financial support within the frame of the Horizon 2020 project BELENUS (G.A. No. 815147).

Acknowledgments: The authors acknowledge the European platform KMM-VIN for supporting the collaboration between VTT and INTA. INTA also thanks the area of Metallic Materials in INTA for technical support, in particular Helena Sanz for the metallographic characterization.

Conflicts of Interest: The authors declare no conflict of interest.

\section{References}

1. Viswanathan, R.; Coleman, K.; Rao, U. Materials for ultra-supercritical coal-fired power plant boilers. Int. J. Press. Vessel. Pip. 2006, 83, 778-783. [CrossRef]

2. U.S. DOE Nuclear Energy Research Advisory Committee and the Generation IV International Forum, A Technology Roadmap for Generation IV Nuclear Energy Systems. 2002. Available online: http://gif.inel.gov/ roadmap/pdfs/gen_iv_roadmap.pdf (accessed on 27 August 2020).

3. Khan, M.F.; Adesina, A.Y.; Khan, S.; Ul-Hamid, A.; Al-Hems, L.M. Corrosion Evaluation and Material Selection for Supercritical Water Reactor Used for Heavy Oil Upgradation. Oxid. Met. 2019, 91, 525-559. [CrossRef]

4. Knödler, R.; Straub, S. Steam oxidation of martensitic steels and of Ni-Base alloys: Comparison of lab tests with operating power plants. Oxid. Met. 2014, 82, 113-122. [CrossRef]

5. Holcomb, G.R. High Pressure Steam Oxidation of Alloys for Advanced Ultra-Supercritical Conditions. Oxid. Met. 2014, 82, 271-295. [CrossRef]

6. Li, W.; Huang, X.; Li, J.; Woo, O.T.; Sánchez, R.; Bibby, C.D. Effect of Pressures on the Corrosion Behaviours of Materials at $625^{\circ}$ C. J. Miner. Met. Mater. Soc. 2017, 69, 207-217. [CrossRef]

7. Akhiani, H.; Nezakat, M.; Penttilä, S.; Szpunar, J. The oxidation resistance of thermo-mechanically processed Incoloy 800HT in supercritical water. J. Supercrit. Fluids 2015, 101, 150-160. [CrossRef]

8. Li, H.; Cao, Q.; Zhu, Z. Oxidation behaviour of Super $304 \mathrm{H}$ stainless steel in supercritical water. Corros. Eng. Sci. Technol. 2018, 53, 293-301. [CrossRef]

9. Zhu, Z.; Xu, H.; Khan, H.I.; Jiang, D.; Zhang, N. Effect of Exposure Temperature on Oxidation of Austenitic Steel HR3C in Supercritical Water. Oxid. Met. 2018, 91, 77-93. [CrossRef]

10. Behnamian, Y.; Mostafaei, A.; Kohandehghan, A.; Amirkhiz, B.S.; Serate, D.; Sun, Y.; Liu, S.; Aghaie, E.; Zeng, Y.; Chmielus, M.; et al. A comparative study of oxide scales grown on stainless steel and nickel-based superalloys in ultra-high temperature supercritical water at $800{ }^{\circ} \mathrm{C}$. Corros. Sci. 2016, 106, 188-207. [CrossRef]

11. Chen, H.; Tang, R.; Long, C.; Le, G. Effect of exposure temperature on the corrosion behaviors of TP347H austenitic stainless steel in supercritical water. Corros. Sci. 2019, 161, 108188. [CrossRef]

12. Agüero, A.; Muelas, R.; González, V. HVOF coatings for steam oxidation protection. Mater. Corros. 2008, 59, 393-401. [CrossRef]

13. Haynes, J.A.; Armstrong, B.L.; Kumar, D.; Dryepondt, S.; Zhang, Y. Oxidation of Slurry Aluminide Coatings on Cast Stainless Steel Alloy CF8C-Plus at $800{ }^{\circ} \mathrm{C}$ in Water Vapor. Oxid. Met. 2013, 80, 363-387. [CrossRef]

14. Schmidt, D.; Galetz, M.; Schutze, M. Ferritic-martensitic steels: Improvement of the oxidation behavior in steam environments via diffusion coatings. Surf. Coat. Technol. 2013, 237, 23-29. [CrossRef]

15. Pedraza, F.; Boulesteix, C.; Proy, M.; Lasanta, I.; de Miguel, T.; Illana, A.; Pérez, F.J. Behavior of Slurry Aluminized Austenitic Stainless Steels under Steam at 650 and $700{ }^{\circ}$ C. Oxid. Met. 2017, 87, 443-454. [CrossRef] 
16. Agüero, A.; Baraibar, I.; Gutierrez, M.; Hernandez, M.; Muelas, R.; Rodriguez, S. Biomass corrosion behavior of steels and Coatings in Contact with $\mathrm{KCl} / \mathrm{K} 2 \mathrm{SO} 4$ at $550{ }^{\circ} \mathrm{C}$ under an oxy-fuel combustion atmosphere: A screening laboratory test. Surf. Coat. Technol. 2018, 350, 188-200. [CrossRef]

17. Agüero, A.; Gutiérrez, M.; Muelas, R.; Spiradek-Hahn, K. Overview of steam oxidation behaviour of Al protective oxide precursor coatings on P92. Surf. Eng. 2016, 34, 30-39. [CrossRef]

18. Medvedovski, E.; Dudziak, T. Protective coatings for high temperature steam oxidation in coal-fired power plants. Surf. Coat. Technol. 2019, 369, 127-141. [CrossRef]

19. Yang, Z.; Lu, J.; Zhang, P.; Le, M.; Zhou, Y.; Huang, J.; Yuan, Y.; Gu, Y. Oxidation performance and degradation mechanism of the slurry aluminide coating deposited on Super $304 \mathrm{H}$ in steam at $600-650{ }^{\circ} \mathrm{C}$. Surf. Coat. Technol. 2020, 391, 125700. [CrossRef]

20. Selvig, A.; Huang, X.; Kim, D.J.; Guzonas, D. Surface oxide formation on IN625 and plasma sprayed NiCrAlY after high density and low density supercritical water testing. Mater. Corros. 2012, 65, 768-777. [CrossRef]

21. Sáez-Maderuelo, A.; McTaggart, M.; Huang, X.; Maffiotte, C. Microstructure Study of NiCrAlY and FeCrAlY Exposed to Superheated Steam at $800^{\circ}$ C. J. Nucl. Eng. Radiat. Sci. 2017, 4, 011015. [CrossRef]

22. Hui, R.; Cook, W.; Sun, C.; Xie, Y.; Yao, P.; Miles, J.; Olive, R.; Li, J.; Zheng, W.; Zhang, L. Deposition, characterization and performance evaluation of ceramic coatings on metallic substrates for supercritical water-cooled reactors. Surf. Coat. Technol. 2011, 205, 3512-3519. [CrossRef]

23. Agüero, A.; González, V.; Gutiérrez, M.; Knödler, R.; Muelas, R.; Straub, S. Comparison between field and laboratory steam oxidation testing on aluminide coatings on P92. Mater. Corros. 2011, 62, 561-568. [CrossRef]

24. Oksa, M.; Tuurna, S.; Metsäjoki, J.; Penttilä, S. Oxidation Performance Coating for Future Supercritical Power Plants. J. Nucl. Eng. Radiat. Sci. 2015, 2, 011018. [CrossRef]

25. Boulesteix, C.; Kolarik, V.; Pedraza, F. Steam oxidation of aluminide coatings under high pressure and for long exposures. Corros. Sci. 2018, 144, 328-338. [CrossRef]

26. Tepylo, N.; Huang, X.; Jiang, S.; Penttila, S. Performance of Aluminide and Cr-modified Aluminide Pack Cementation Coated Stainless Steel 304 in Supercritical Water (SCW) at $700{ }^{\circ}$ C. J. Nucl. Eng. Radiat. Sci. 2019, 5, 011014. [CrossRef]

27. Agüero, A.; Gutiérrez, M.; González, V. Deposition process of slurry iron aluminide coatings. Mater. High Temp. 2008, 25, 257-265. [CrossRef]

28. Agüero, A.; González, V.; Gutiérrez, M.; Muelas, R. Oxidation under pure steam: Cr based protective oxides and coatings. Surf. Coat. Technol. 2013, 237, 30-38. [CrossRef]

29. Boiler Grade DMV 347 HFG. Available online: https://www.mannesmann-stainless-tubes.com/files/smst_ booklet_347hfg_2008.pdf (accessed on 27 August 2020).

30. Mouayd, A.A.; Koltsov, A.; Sutter, E.; Tribollet, B. Effect of silicon content in steel and oxidation temperature on scale growth and morphology. Mater. Chem. Phys. 2014, 143, 996-1004. [CrossRef]

31. Bischoff, J.; Motta, A.T. Oxidation behavior of ferritic-martensitic and ODS steels in supercritical water. J. Nucl. Mater. 2012, 424, 261-276. [CrossRef]

32. Zhu, Z.; Jiang, D.; Cao, Q.; Xu, H.; Khan, H.I.; Zhang, N. Oxidation behavior of austenitic steel Sanicro 25 and TP347HFG in supercritical water. Mater. Corros. 2019, 70, 1087-1098. [CrossRef]

33. Rouillard, F.; Moine, G.; Martinelli, L.; Ruiz, J.C. Corrosion of $9 \mathrm{Cr}$ steel in $\mathrm{CO}_{2}$ at intermediate temperature I: Mechanism of void-induced duplex oxide formation. Oxid. Met. 2011, 77, 27-55. [CrossRef]

34. Rouillard, F.; Martinelli, L. Corrosion of $9 \mathrm{Cr}$ steel in $\mathrm{CO}_{2}$ at intermediate temperature III: Modelling and simulation of void-induced duplex oxide growth. Oxid. Met. 2011, 77, 71-83. [CrossRef]

35. Chen, H.; Kim, S.H.; Kim, C.; Chen, J.; Jang, C. Corrosion behaviours of four stainless steels with similar chromium content in supercritical carbon dioxide environment at $650{ }^{\circ}$ C. Corros. Sci. 2019, 156, 16-31. [CrossRef]

36. Halvarsson, M.; Tang, J.; Asteman, H.; Svensson, J.-E.; Johansson, L.-G. Microstructural investigation of the breakdown of the protective oxide scale on a 304 steel in the presence of oxygen and water vapour at $600{ }^{\circ} \mathrm{C}$. Corros. Sci. 2006, 48, 2014-2035. [CrossRef]

37. Agüero, A.; Spiradek, K.; Hofinger, S.; Gutiérrez, M.; Muelas, R. Microstructural Evolution of Slurry Fe Aluminide Coatings during High Temperature Steam Oxidation. Mater. Sci. Forum 2008, 595, 251-259. [CrossRef]

38. Holcomb, G.R. Steam Oxidation and Chromia Evaporation in Ultra-Supercritical Steam Boilers and Turbines. ECS Trans. 2009, 16, 44. [CrossRef] 
39. Huang, X.; Li, J.; Amirkhiz, B.; Liu, P. 2015. Effect of Water Density on the Oxidation Behaviour of A-286 at $625^{\circ}$ C. J. Nucl. Eng. 2015, 467, 758-769.

40. Zhang, N.; Cao, Q.; Gui, J.; Li, M.; Xu, H. Oxidation and chromia evaporation of austenitc steal TP347HFG in supercritical water. Mater. High Temp. 2018, 35, 461-468. [CrossRef]

(C) 2020 by the authors. Licensee MDPI, Basel, Switzerland. This article is an open access article distributed under the terms and conditions of the Creative Commons Attribution (CC BY) license (http://creativecommons.org/licenses/by/4.0/). 